\title{
Corporeity and teacher practice in the education of the field in the Paraense Amazon
}

\author{
RODRIGUES, Rosenilma Branco (Brasil, Pará, Santarém) ${ }^{1 *}$ \\ COUTO, Hergos Ritor Fróes de (Brasil, Pará, Santarém) ${ }^{1^{\star *}}$ \\ 'Universidade Federal do Oeste do Pará \\ ORCID ID: https://orcid.org/0000-0003-2058-4341* \\ ORCID ID: https://orcid.org/0000-0002-0101-4012*
}

\begin{abstract}
The objective of this study was to investigate, from the foundations of Corporeity and Field Education, the meanings that teachers attribute to the body in teaching practice in the rural territories of Santarém, located in the Amazon Paraense. Methodologically, it is a qualitative study with a phenomenological approach, organized in two stages: bibliographical and field research. For the production and analysis of data, we used the Technique of Elaboration and Analysis of Units of Significance, developed by Moreira, Simões and Porto (2005). Theoretical developments impute a dialogue between Corporeity and Field Education, supported by authors who evoke the themes. Field data focused on subjects' discourse, through which it was found that they comprehend the body in its totality, with multiple possibilities of knowledge and social interaction. As well, it has been verified that there are experiences of corporeity in the teaching practice with valorization of the peasant knowledge.
\end{abstract}

\section{Keywords}

Amazon. Field Education. Corporeity experiences.

\section{Corporeidade e prática docente na Educação do Campo}

\author{
na Amazônia paraense
}

\begin{abstract}
Resumo
Este trabalho teve como objetivo investigar, a partir dos fundamentos da Corporeidade e Educação do Campo, os sentidos que os professores atribuem ao corpo na prática docente nos territórios rurais de Santarém, localizado na Amazônia paraense. Metodologicamente é um estudo qualitativo com abordagem fenomenológica, organizado em duas etapas: pesquisa bibliográfica e de campo. Para a produção e análise dos dados, utilizou-se da técnica de elaboração e análise de unidades de significado, desenvolvida por Moreira, Simões e Porto (2005). Os desdobramentos teóricos imputam um diálogo entre Corporeidade e Educação do Campo, sustentando-se em autores que evocam sobre as temáticas. Os dados de campo centraram-se no discurso dos sujeitos, por meio dos quais se constatou que eles compreendem o corpo em sua totalidade, com múltiplas possibilidades de saberes e interação social, bem como verificou-se que há vivências de Corporeidade na prática docente com valorização dos saberes camponeses.
\end{abstract}

\section{Palavras-chave}

Amazônia. Educação do Campo. Vivências de Corporeidade. 


\title{
Corporeidad y práctica docente en la Educación del Campo
}

\author{
en la Amazonia paraense
}

\begin{abstract}
Resumen
Este trabajo tuvo como objetivo investigar, a partir de los fundamentos de la Corporeidad y Educación del Campo, los sentidos que los profesores atribuyen al cuerpo en la práctica docente en los territorios rurales de Santarém, en la Amazonia paraense. Metodológicamente es un estudio cualitativo con enfoque fenomenológico, organizado en dos etapas: investigación bibliográfica y de campo. Para la producción y análisis de los datos, se utilizó de la técnica de elaboración y análisis de unidades de significado, desarrollada por Moreira, Simões y Oporto (2005). Los desdoblamientos teóricos imputan un diálogo entre Corporeidad y Educación del Campo, sosteniéndose en autores que evocan sobre las temáticas. Los datos de campo se centraron en el discurso de los sujetos, a través de los cuales se constató que ellos comprenden el cuerpo en su totalidad, con múltiples posibilidades de saberes e interacción social, así como se verificó que hay vivencias de Corporeidad en la práctica docente con valorización de los saberes campesinos.
\end{abstract}

Palabras clave

Amazonas. Educación del Campo. Vivencias de Corporeidad.

\section{INTRODUCTION}

The body is a constant, intriguing theme, which has caused and continues to cause agreements and disagreements about several concepts concerning it, developed throughout the history of humankind. Societies live according to their own time and space, which fosters social dynamics that enable the idea of body structured according to the cultural production of each period, generating diverse meanings and significance.

In Western cultures, especially in Plato's thinking, we notice that the body is oriented towards gymnastics as a form of education for citizens. In the Middle Age, Saint Augustine took up the Platonic ideas that divided human beings into body and soul, adding another element that would animate the soul: divinity - God. Rousseau brings his considerations on the education of Emile, a pedagogical novel that criticizes traditional education, which, focusing on progress, induces children to develop their intellect, forgetting physical education and other human dimensions, such as building moral character (NÓBREGA, 2010). 
In effect, the Modern Age is an important landmark in the production of knowledge, whence emerge theories that question the human capability to know, resulting in the epistemological questions that emphasize that issue: rationalism (emphasizes learning through reason) and empiricism (emphasizes learning through experiences), both of which progressed separately for a long time, affirming themselves as theories of knowledge. Rationalism, even before Rousseau's Enlightenment ideas, was the first philosophical current concerning the theory of knowledge, and its main representative is René Descartes.

Descartes, creator of the Cartesian method, sought to develop a safe and universal method that led to unquestionable truth. Therefore, he had as a base purely rational knowledge. Dividing human beings into body and mind, he attributed to the latter the faculty of intelligence, of knowledge, denying the capability of the senses as means for learning. In this context, the defense that knowledge takes place through perception fell upon empiricists, especially David Hume. Empiricist John Locke, opposing the rationalist ideal, criticizes Descartes's doctrine of innate ideas and compares the soul to a clean slate, without knowledge, because it will be produced and reproduced through sensitive experiences.

Rationalism imparts the limitation of physical experiences in the process of knowledge construction. This idea is disseminated in teaching institutions, resulting in traditionalism, mechanical education, disciplining and the concept of the body-object. That which is manipulated and turned docile; "[...] docile is the body that can be subdued, that can be used, that can be transformed and perfected" (FOUCAULT, 2014, p. 134, our translation).

Foucauldian corroborations uphold that models originated in the capitalist system strongly influenced the functioning of schools, for example, the rules implemented in factories. This industrial model was carried over to schools, turning them into a reference as regulator and oppressor of their students' physical manifestations, legitimizing discipline and docilization as school control and organization. On the other hand, school can, at the same time, transcend educational experiences through physical experiences. We highlight that rationalism, despite elevating the disqualification of the body, was the guiding axis to problematize it as a research object, starting in the $20^{\text {th }}$ century.

Educação \& Formação, Fortaleza, v. 5, n. 13, p. 113-131, jan./abr. 2020 
In the context of rural territories, the idea of body-object was easily verifiable, since the model of "rural education" that was in place didn't seek the development of peasant subjects, but the interests of capitalism in exploiting labor. These people were treated as if their bodies were objects, devoid of yearning, pain and sorrow, serving as a tool to produce food for major urban centers.

The dehumanization that characterized "rural education" implies the idea of a body-object, as denounced by Foucault (2014), over oppressed, docilized bodies, domesticated to meet the oppressors' demands. "In this perspective, the body is seen as an object to be disciplined, aiming toward physical and moral improvement of people, efficiency and productivity of an industrial society" (NÓBREGA, 2005, p. 45, our translation).

The transition from rural education to Field Education is marked by social organization and mobilization in the defense of an education aimed at the interests and needs of those who live off and in the land.

Confronting the denied rural education, the field education created by popular movements of fight for the land organized in peasant movement articulates productive work and school education, with cooperation as a base. Field education doesn't admit the interference of outside models and is part of a popular project of society, inspired by and subsisting of peasant solidarity and dignity. (RIBEIRO, 2012, p. 300, our translation).

Therefore, advocating for corporeity in education, particularly in Field Education, stems from a concern and need to see the teaching-learning process as a mechanism for social development, emancipating, democratic and human (COUTO, 2008; GONÇALVES, 2012; MOREIRA, 2014; NÓBREGA, 2005, 2010). In this context, the body is understood as the condition of human existence and takes part in a social and historical construction; through the body, we outline aspirations of our subjectivity and interact with others and with the world (MOREIRA, 2014). Corporeity in the educational process emphasizes:

[...] the need for this new pedagogical attitude, not concerning ourselves with criticism or denials to what is already established. Seeking the presence of corporeity in school means overcoming current patterns in understanding and in working with the body of students in a school environment, writing and experiencing a new history, at the same time that we are aware of being changed by this dialogical history. (MOREIRA, 2014, p. 152, our translation). 
Corporeity takes place as a possibility of reflection on established educational patterns that deny the body as a means for learning and through which the individual is developed. If education, as a means for change and the development of human beings, downplays or denies the importance of the body in the construction of knowledge, it stops performing its social, democratic and critical role.

In this regard, considering the importance of corporeity in educational qualification, especially school qualification, and in paradigm change, we sought to investigate, grounded on the foundation of Corporeity and Field Education, the meanings that teachers attribute to the body in teacher practice in the rural territory of Santarém, located in the Pará Amazon. The meanings mentioned in the objective will be identified in the discourse of teachers who work in rural territories.

\section{METHODOLOGICAL PATH}

The study took place in the municipality of Santarém, located in the Pará Amazon. According to the 2017 Census of the Santarém Education Secretariat, the majority of schools (corresponding to over 200 schools) is located in rural territories. It is important to highlight some perceived difficulties, such as: some classes have multiple grade levels, schools are hard to access and lack physical and pedagogical structure. On the other hand, they have abundant sociocultural diversity. We can emphasize that the Santarém Education Secretariat, for the purpose of educational management, divided school locations into urban areas, plateaus (grouping schools whose access happens by land) and rivers (whose access happens by river). River and plateau schools also encompass indigenous and quilombola schools.

This study took place at a river school located in Vila Lago Grande do Curuai, where the river's flood and ebb determine the lives of people who live there. The river is one of the paths that children take to school, using boats as means of transportation, whereas by land they usually walk or ride bicycles; students are mostly from the community, but some come from farther places. We emphasize that the main economic activities are agriculture and fishing.

The criteria used to choose the research locus were: a school in the rural territory, riverside, with a high concentration of students, located in Lago Grande do 
Curuai (a place of personal reference for the researchers), with teachers who work with elementary school $-1^{\text {st }}$ to $5^{\text {th }}$ grade.

In the school, there were eight teachers working with those grades, so they were the research subjects according to the established criteria. We followed the ethical aspects of scientific research, providing an Informed Consent Form to be signed and maintaining secrecy of the subjects' identities. Each teacher chose the name that would identify them in the research. According to the description in tables 1 and 2, the names chosen were: Tânia, Pajurá, Mary, Great Kiskadee, Helen, Eva of Roses, Violet and Maria. They had between 15 and 33 years of experience on the job, most of them steadily, with the exception of Pajurá, who had two months of teaching experience, since six months earlier she was in undergraduate school, in the Pedagogy course. Before being a teacher, she had an administrative job at the school. Out of the teachers researched, only one had worked at schools in the urban area, the others had experience only in the rural area.

This study is considered qualitative in nature, with a phenomenological approach. Qualitative research enables proximity between the researcher and the researched object, besides the ability to enter the universe of meanings in human relationships. According to Minayo (1994, p. 21, our translation), qualitative research is concerned:

[...] with a level of reality that cannot be quantified. That is, it works with the universe of meanings, motives, aspirations, beliefs, values and attitudes, which corresponds to a deeper space of relationships, processes and phenomena that cannot be reduced to the operability of variables.

The phenomenological approach takes place through the intentionality of the researcher toward the researched object, considering the social context of the research subjects who were important elements for the interpretation of the data. We understand that the teachers' discourse, the main analysis object, is loaded of meaning, significance and values. According to Siani, Corre and Casas (2016, p. 193, our translation):

The phenomenological approach, as a procedure guideline, unfolds in two great branches: philosophical and empiric. In both branches, the starting point is the subjects' social reality and the objective is their understanding. In the philosophical sphere, this understanding is always centered on the one who conducts the analysis of a phenomenon to the extent of its essence. In the empiric sphere, the analyzed object is always a fraction of 
the other's world. The apprehension of this fraction results, forcefully, in the obtention of reports concerning the other's lived experience in order to reach the phenomenon, i.e., the 'thing itself'.

In the context of the teachers' lived experience, we considered that the researched school has setbacks that interfere with their practice, such as: long distances traversed by students, the families' lack of financial structure and the absence of the own family while co-responsible for the children's upbringing. Concerning the teacher with little classroom experience, her difficulties are justified by her still incomplete academic training and lack of teaching experience. All those factors, although not the analytical focus of this research, are linked to the teaching-learning process and, therefore, present in the teachers' discourse.

It is important to remember that another factor that justifies opting for a phenomenological approach consists of choosing the tool for data production and analysis, the Technique of Elaboration and Analysis of Units of Significance, developed by Moreira, Simões and Porto (2005). We emphasize that, according to the authors, "[...] the theoretical/epistemological structure of the proposal is linked to phenomenological presumptions, especially in the work of Merleau-Ponty concerning the phenomenon of corporeity" (MOREIRA; SIMÕES; PORTO, 2005, p. 107, our translation). This technique consists of three moments: candid report; attitude identification; and interpretation.

The first moment took place through a semi-structured interview, with two questions: What is body for you? What meanings do you attribute to the body in your teaching practice? The second moment involved the selection of units of significance based on the reports organized according to tables 1 and 2. And the third moment took place with the analysis of units of significance, with the help of the theoretical framework for the support and/or confrontation of ideas. The technique anticipates that the second question be asked after the first question is answered, thus avoiding interference in the first answer. It is valid to highlight that the research took place through bibliographic survey and field research. 


\section{CORPOREITY AND FIELD EDUCATION IN THE AMAZON: WHAT THE SUBJECTS} SAY

In the beginning of the interview, the first question was "What is body for you?". Before answering, all subjects requested time to reflect about the question, because, according to them, they hadn't questioned that before. Based on the answers, the data are interpreted below:

Table 1 - Unit of significance related to the question: "What is body for you?"

\begin{tabular}{|c|c|c|c|c|c|c|c|c|c|}
\hline Subjects & & & & & & & & & \\
\hline Units of significance & 学 & $\frac{\sqrt{\pi}}{\sqrt[\pi]{\pi}}$ & $\frac{2}{\pi}$ & 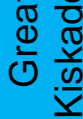 & $\frac{\bar{\omega}}{\bar{\Phi}}$ & 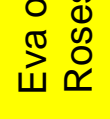 & $\frac{0}{\circ}$ & $\sum^{\frac{0 \pi}{\pi}}$ & 要 \\
\hline The body is everything in our life. & $\mathrm{X}$ & & $\mathrm{X}$ & & $\mathrm{x}$ & $X$ & & & 4 \\
\hline A machine. & & & $x$ & & & & & & 1 \\
\hline $\begin{array}{l}\text { Body is everything that has mass and } \\
\text { occupies a place in physical space. }\end{array}$ & & & & $\mathrm{X}$ & & & & & 1 \\
\hline It is present in every moment. & $\mathrm{X}$ & & & $\mathrm{X}$ & $\mathrm{X}$ & $\mathrm{X}$ & & $\mathrm{x}$ & 5 \\
\hline The body is a whole. & & $\mathrm{X}$ & $\mathrm{X}$ & $\mathrm{X}$ & $\mathrm{X}$ & $\mathrm{X}$ & $\mathrm{X}$ & $\mathrm{X}$ & 7 \\
\hline
\end{tabular}

Source: Elaborated by the author (2017).

For seven teachers - the body is a whole. This understanding seeks to view the body beyond its biological structures and that human actions depend on the conditions in which it is developed. The body needs to be well in itself in order to engage with the other:

[...] so if the body isn't functioning well, of course nothing is going to work well, [...] for you to do a good job the body needs to be in good action. (VIOLET, our translation).

[...] group of organs, which work along with each other, and each has a different function, but it is necessary that they are in sync to work well. (MARIA, our translation).

This totality evidenced in the subjects' point of view is reflected on the concept of human totality defended by Edgar Morin (2011), in which human beings aren't only biological organisms nor only cultural beings, but an interweaving of those two dimensions. Human beings have an existential complexity that guarantees them the 
possibility of multiple experiences. In the case of Field Education, the experiences are related, mainly, to natural spaces and the families' lifestyles.

Analyzing Table 1, five interviewees stated that - the body is present in every moment. Thus ascertains Eva of Roses (our translation): "The whole day your body it does everything, walk, make movements, think. Some days it is sad, some days it is happy [...]". According to Gonçalves (2012, p. 102, our translation): "[...] we are presence through the body - the body is presence, which at the same time hides and reveals our way of being-in-the-world". As a body, humans exist, because "[...] minds don't inhabit corpses" (FREIRE, 1991, p. 26, our translation).

The body is everything in our life - so stated four teachers. The interviewees sought to evidence that the body is the main means of locomotion, socialization and production, as is well observed in the discourse of teacher Helen. The body is a group of parts responsible for the individual's actions, such as thinking and moving. "[...] our body it has to be prepared, [...] our parts they have to be prepared to face everyday life in our way of thinking, acting, moving to carry out this job in our workplace" (HELEN, our translation).

For another teacher, the body is - everything that has mass and occupies a place in physical space. This is Great Kiskadee's statement; her arguments concern existence, the body as something visible, tangible and responsible for the communication with others.

[...] everything around us is a body [...] we are beings who are always in physical space, [...] we are a body, in person, so before our students we are, they see us like a space, in this case physical, they see us communicate with them through gestures, through movement, so all this I believe is in the physical space around us. (GREAT KISKADEE, our translation).

As a counterpoint, a teacher refers to the body as - a machine. Teacher Mary (our translation) emphasizes:

[...] a machine when it has a problem in a part, it goes out of control, we are not going to do anything, not even get to work and a person cannot do anything [...] without health. So in our body [...] like a machine that works, because if a part breaks or we get all out of control, like, not able to do anything. 
The machine body induces the idea of body-object, linked to the Cartesian view that fragments it, turning it into an oppressed and alienated body, unable to think for itself. For Foucault (2014), the body is treated like a machine that follows commands and its presence is useful only for the production system. "[...] the human body enters a machinery of power that scrutinizes, takes it apart and restores it" (FOUCAULT, 2014, p. 135, our translation).

The understanding of the machine body was overcome by Field Education, because "[...] the vision of field in Field Education requires in itself a broader view of education of people, as it thinks the logic of country life as a totality in its multiple and diverse dimensions" (CALDART, 2008, p. 78, our translation). Generally, for most interviewees, the body is the possibility of existence for the individual.

After they answered the first question, we questioned the following (Table 2):

Table 2 - Unit of significance related to the question: "What meanings do you attribute to the body in your teaching practice?"

\begin{tabular}{|c|c|c|c|c|c|c|c|c|c|}
\hline & & & & & & & & & \\
\hline Units of Significance & 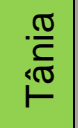 & 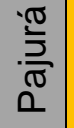 & $\stackrel{\frac{\pi}{\pi}}{2}$ & 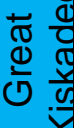 & $\frac{\frac{c}{\omega}}{\frac{\omega}{I}}$ & 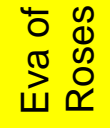 & $\frac{\overleftarrow{\mathrm{\omega}}}{\frac{\mathrm{O}}{\mathrm{O}}}$ & 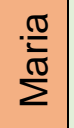 & $\begin{array}{l}\bar{\sigma} \\
\text { 음 }\end{array}$ \\
\hline Transmitter and recipient of knowledge. & & $\mathrm{x}$ & & & & & & & 1 \\
\hline $\begin{array}{l}\text { Means to contribute to the children's } \\
\text { knowledge. }\end{array}$ & & & $\mathrm{X}$ & & $\mathrm{x}$ & $\mathrm{X}$ & $\mathrm{X}$ & $\mathrm{x}$ & 5 \\
\hline Relationship of dialogue and respect. & $\mathrm{X}$ & & $\mathrm{x}$ & & & & $\mathrm{x}$ & $\mathrm{X}$ & 4 \\
\hline $\begin{array}{l}\text { The student's body is movement, gestures, } \\
\text { is their behavior. }\end{array}$ & $x$ & & & $\mathrm{x}$ & $\mathrm{X}$ & $\mathrm{X}$ & $\mathrm{x}$ & & 5 \\
\hline It's oriented toward reading. & & $\mathrm{x}$ & & $\mathrm{x}$ & $\mathrm{x}$ & & & $\mathrm{x}$ & 4 \\
\hline $\begin{array}{l}\text { Relationship family, school, teacher and } \\
\text { child. }\end{array}$ & & & $\mathrm{X}$ & & & $\mathrm{X}$ & & $\mathrm{X}$ & 3 \\
\hline $\begin{array}{l}\text { There isn't a model of student, each person } \\
\text { is a person. }\end{array}$ & & & & $\mathrm{X}$ & & $\mathrm{x}$ & & $\mathrm{x}$ & 3 \\
\hline $\begin{array}{l}\text { Feel (student) well at school too, that they } \\
\text { want to learn. }\end{array}$ & $x$ & & & & & $\mathrm{x}$ & $\mathrm{x}$ & $\mathrm{x}$ & 4 \\
\hline
\end{tabular}

Source: Elaborated by the author (2017).

On table 2, we notice that the meaning of the student's body for most teachers is - Means to contribute to the children's knowledge - and five teachers share this view. The educators showed intentionality to contribute to the students' development beyond 
the classroom, seeing them as social actors capable of constituting their own histories and overcoming social conflicts in which they are immersed.

Therefore, the teachers seek to turn the school into a tool for social change, through the upbringing of critical citizens. This assertion is noticeable in teacher Mary's discourse, who starts her answer by comparing the body to a machine, however, the way she puts it, the deal she makes with students is an unlikely task for a machine:

I think it's like a machine to sustain many things, many people, many beings, that I may also take these pieces, these children next to me and help, contribute to the knowledge of these children, these beings I'm working with, the human being. And educating a child, which is the objective of a professional, of a teacher who works with children, the objective is getting a child who can express themselves, can communicate wherever they get [...] we are involved in a project where I take part [...] now in the last payday, I went and bought toys to bring, that every year I always buy toys, this year unfortunately I can't get them for everyone. (MARY, our translation).

Teacher Mary mentions the concern to provide, to the children, new experiences through play. The project she referred to is related to Children's Day, and she grieves that the available financial resources weren't enough to buy toys for everyone, because she knows how much they expected to get toys, and, worried about them being sad, she promises a hug; which may mean more then even the toys. In this case, the children in the country suffers with financial scarcity, which impairs gifting toys.

For Helen and Violet, the job of the teacher, although challenging, demands understanding the students based on the need to be children, to play, to move, and offering them safety. In this aspect, according to Violet, the expressiveness of the body is important for the teacher's practice, since, through it, she communicates with the students, and this communication process is relevant in the definition of teaching methodologies. Fernandes, Cerioli and Caldart (2005, p. 54, our translation) state that:

[...] ethic/moral commitment to each and from each participant in our educational practice, while human, singular and social people, who have needs, interests, desires, knowledge, culture, and who deserve respect, availability and seriousness from educators, entities, governments. This commitment has as one of its consequences the effort we must make to translate other commitments into public policies, pedagogical relationships and teaching methodologies.

Educação \& Formação, Fortaleza, v. 5, n. 13, p. 113-131, jan./abr. 2020

DOI: https://doi.org/10.25053/redufor.v5i13.1439

http://seer.uece.br/redufor 
The relevance of being an educator consists of their contribution for human qualification, preparing to combat social, political and cultural challenges that permeate the reality of society. According to Gerone Junior and Hage (2013), being a riverside teacher exceeds the classroom limits, with functions that, in theory, aren't part of the academic demands for an educator.

For five teachers - the student's body is movement, gestures, is their behavior. To them, the body is the first form of contact and, therefore, the first communication with students. The intentionality of movement is expressed in the body.

The student's body in the classroom has a lot of meaning, their movement, the gestures, how they act in the classroom, their behavior, when we are expressing ourselves to them, when we draw their attention, how I know, this class are restless students, so they are always moving, they don't stay quietly in one place, they are always in physical movement, they're not students who are quiet in that place, they occupy their space, in their moment [...] a quiet student doesn't mean they're learning, they are quiet, but they aren't understanding. So they express the way, the manner they are in the classroom, but they still learn something. (GREAT KISKADEE, our translation).

In her discourse, teacher Great Kiskadee highlights elements that could generate new studies. This particular speech concerns looking at the students in their diverse uniqueness: the complex body, communicable, intelligible body, a child's body. It is the materiality of the "I am body". She acknowledges the students' development, even if they aren't focused on reading and writing. This teacher was working with a group of students that is part of the program "Se Liga", by the Ayrton Senna Institute (on-line, our translation), which "[...] is intended for illiterate students with discrepancies between age and grade enrolled between the $3^{\text {rd }}$ and $5^{\text {th }}$ grades of elementary school. [...] promotes the full literacy of these students [...]".

The interviewees also stated that movement is necessary to the development of their classes, because it diversifies activities and makes them more dynamic and pleasurable for students. They acknowledge that childhood is founded on different aspects, so there are moments when they offer freedom to the students, when they state that they are free. We emphasize that these moments of greater freedom are still monitored by the teachers, because they understand that children need limits, that is, even when students are making their own choices, the educator's viewpoint is alert and important. According to Freire (2016, p. 70, our translation), "[...] teacher and student 
together, we can learn, be unsettled, produce together and likewise together resist the obstacles to our joy". From the point of view of these teachers, the student needs the educator's guidance. In this regard, there is the conviction that the student is a consequence of the educator's work.

The body, in the understanding of most teachers, consists of the possibility to interact with the other, the first communication with students takes place through it, and it is through the body that we develop activities aimed at teaching-learning. The interviewees know their students' particularities, therefore, their gestures allow the teachers to distinguish them, turning changes in these children's routines visible for teachers, because each gesture has one or several revealed and interpreted meanings.

According to Merleau-Ponty (2011, p. 251, our translation), the "[...] meaning of gestures isn't given, but understood, that is, recovered by an action of the spectator". With this, we obtain "[...] the communication or the comprehension of gestures through the reciprocity between my intentions and the other's gestures, between my gestures and intentions readable in the other's conduct" (MERLEAU-PONTY, 2011, p. 251, our translation). Concerning this aspect, Nóbrega (2010, p. 36, our translation) corroborates that:

A theory of corporeity must be careful about the multiple meanings of knowledge about the body, seeking not to reduce the phenomenon to simplifying categories, but to allow different looks, different approximations and approaches focusing on dialogue, on the communication between elements that constitute this multifaceted universe.

Concerning communication and the meanings that emerge from body expression, Merleau-Ponty (2011, p. 253, our translation) highlights that: "[...] It is through my body that I understand the other, and it is through my body that I notice things". In the context of riverside schools, Gerone Junior e Hage (2013) verify that reality is very difficult, because the accomplishment of teaching-learning requires, between walks and boat rides to school, overcoming many challenges, such as problems with drugs, crime and the absence of family.

Another meaning attributed to the body by four teachers is - Relationship of dialogue and respect. The teacher Mary mentions the example of two students who migrated from another state. Those students drew the attention of other teachers due to 
their behavior in the classroom, and, in addition, the children's mother warned her that her children would be a handful. With that, the teacher used the strategy of dialogue, stating that the child who lives in urban centers has different experiences than those who live in the country, where there are many possibilities for play exploring the natural environment.

Besides these aspects, we also determined that teachers have been seeking to integrate children into a critical thinking process, learning to respect others and themselves. School is a place to seek other possibilities of life, broaden knowledge, interact with other people. According to Gerone Junior and Hage (2013), school can be a happy, dynamic place, as well as serious and competent; one quality doesn't diminish the other, because, discussing school, we refer to education, teaching and learning.

The teachers who bet on dialogue and respect understand the importance of childhood. The children don't have to be "tiny adults" to have truth in their experience, because speech, thoughts and actions are full of meanings and significance. In this case, as Gerone Junior and Hage (2013, p. 31, our translation) discuss, "[...] the teacher, then, starts to be the subject who cares and looks at the student, establishing a relationship of affection and commitment". The teacher's practice is permeated by the commitment to the child's development.

Another relevant unit is making the students feel well at school, help them want to learn - four teachers have that understanding. They experiment with many strategies in order to turn the school and the classroom into spaces for learning, social interaction, respect and partnership.

\begin{abstract}
Our challenges are adverse situations that we find in the classroom where we are always trying to do something so that the student can learn, [...] our objective is that they leave not how they arrived, nor worse, but that they leave better than they arrived, that they feel well at school, that they want to learn [...] to like the school, stay longer, want to be at school, so we start feeling like there was a change in behavior. (MARIA, our translation).
\end{abstract}

According to four people, the body in the classroom - it is oriented toward reading. As Maria identifies: "[...] started also to learn things they didn't know, for example, couldn't read, or write well [...]". However, the spaces for that activity, according to data, show that: " $79.1 \%$ of those enrolled in urban schools have access to a library or reading room. The situation of those enrolled in the rural area is different, $35.4 \%$ of them 
have access to those spaces at the school they attend" (INEP, 2017, p. 14, our translation). We observe that in rural schools there is a lack of appropriate spaces for reading.

In this context, exercising the teaching practice becomes challenging, therefore, teachers, when attributing meaning to the body, two units of significance converge for three teachers - Relationship family, school, teacher and child; There isn't a model of student, each person is a person.

According to the interviewees, the relationship family and school is characterized as a partnership that influences the process of teaching-learning and, therefore, the development of the student; without it, the challenges of teacher's practice are even greater. This relationship, although not the focus of analysis in this research, emerged in the teachers' discourse, so it is relevant to discuss. The unit - There isn't a model of student, each person is a person refers to the complexity in working with diverse types of behaviors and different realities. Therefore, teachers seek to idealize actions that may assist the students' needs, aiming to involve them in planned actions:

[...] there isn't a model of student, each person is a person and a different behavior, different needs, difficulties, because when it comes to people, we all have limits, we have our limitations. (MARIA, our translation).

[...] we all have many models of student, especially through behavior [...] have to please the children in many ways, there is a way to talk to that child [...] we play some games, in the classroom, ask them to make a movement [...] I am not a teacher that keeps the children sitting all the time, they are always moving. (EVA OF ROSES, our translation).

Opposing the view of body-subject, one teacher states, the body is - Transmitter and recipient of knowledge. It is valid to highlight that at the time of this research, she only had two months of teaching experience in the classroom. She was still in the process of self-recognition in the teaching practice, since before starting Higher Education she had an administrative role at the school. In her evaluation, play isn't something positive for the student's performance, since the ideal is that they focus on the content tasks. According to Freire (2016, p. 25, our translation), "[...] teaching isn't transferring knowledge, content, neither is training an action through which a creator subject shapes, styles, or gives soul to an indecisive or settled body". 
We emphasize that most teachers realize that their role in the classroom goes beyond bureaucratic issues. Regarding the students, they seek to educate them as beings capable of change, especially through all political, economic and social setbacks that insist on making the rural environment a place of regression.

\section{FINAL CONSIDERATIONS}

This research proposed to investigate, based on the foundations of Corporeity and Field Education, the meanings teachers attribute to the body in teaching practice in the rural territories of Santarém, located in the Pará Amazon.

The great challenge of this study was to outline a dialogue between corporeity, territories and Field Education without incurring in what it most questions - fragmentation.

Making the connection between the Corporeity approach and Field Education, we verified the enrollment established by both. Corporeity denies the oppression of the subject, the docilization and silencing of the body. Meanwhile, Field Education, as more than a term that surpasses the understanding of Rural Education, illustrates the overcoming of peasant oppression along decades. Therefore, thinking Field Education reflects the social organization of subjects who seek, through the experience of corporeity, ways to overcome the oppressive conditions to which they have been historically submitted.

Thus, the investigation of meanings attributed to the body by educators in teaching practice in the rural territory of Santarém verified that these meanings denote concern with the children's integral education, which is why, at many points of their speeches, there are issues such as family, financial difficulties, investment in play, among others, that weren't the object of analysis, but that, according to them, influence the teaching practice and, subsequently, the learning process.

Therefore, according to them, the body is a totality, without it there is no human presence, because it needs to be present in all moments of the subject's action. Without the body, there are no actions.

In the meanings attributed to the body by the teachers, the relationship established with the students is evidenced, in which movement and gestures define each student's behavior. For most teachers, a quiet student in the classroom isn't synonymous 
to learning. Therefore, there are moments when the student interacts more through movement, with more significant learning. Thus, the acquisition of knowledge gains more meaning when local specificities, in this case, the riverside modality, are part of the teaching-learning context.

Considering that the body is the materiality of existence, we verified that in the teaching practice of riverside educators, it is a means of communication with the children, through the body they produce and reproduce cultural manifestations, social issues, through it learning takes place. Therefore, the question about meanings attributed to the body in the classroom may not have surprised the teachers, except for the teacher with less experience, because most of them view the relationship between body and the process of teaching and learning naturally.

We verified that, in spite of the issues "body" and "corporeity" not being a commonplace discussion for teachers and, maybe, not being discussed in their academic training, the arguments revealed in their reports still confirm the presence of corporeity in teaching practices.

\section{REFERENCES}

CALDART, R. S. Sobre Educação do Campo. In: SANTOS, C. A. (Org.). Educação do Campo: campo-políticas públicas-educação. Brasília, DF: Incra: MDA. 2008. p. 67-86.

COUTO, H. R. F. A criança e as manifestações lúdicas de rua e suas relações com a educação física escolar. Piracicaba, 2008. 131 f. Dissertação (Mestrado em Educação Física) - Programa de Pós-Graduação em Educação Física, Universidade Metodista de Piracicaba, Piracicaba, 2008.

FERNANDES, B.; CERIOLI, P. R.; CALDART, R. S. Primeira Conferência Nacional "Por Uma Educação Básica do Campo". In: ARROYO, M. G.; CALDART, R. S.; MOLINA, M. C. (Org.). Por uma educação do campo. 5. ed. Petrópolis: Vozes, 2011. p. 19-62.

FOUCAULT, M. Vigiar e punir: nascimento da prisão. Petrópolis: Vozes, 2014.

FREIRE, J. B. De corpo e alma: o discurso da motricidade. São Paulo: Summus, 1991.

FREIRE, P. Pedagogia da autonomia: saberes necessários à prática educativa. 54. ed. Rio de Janeiro: Paz e Terra, 2016.

GERONE JUNIOR, A.; HAGE, S. A. M. Ser professor ribeirinho: os desafios que emergem da educação e da ação pedagógica em escolas ribeirinhas da Amazônia. In:

Educação \& Formação, Fortaleza, v. 5, n. 13, p. 113-131, jan./abr. 2020

DOI: https://doi.org/10.25053/redufor.v5i13.1439

http://seer.uece.br/redufor 
ABREU, W. F.; OLIVEIRA, D. B.; SILVA, É. S. (Org.). Educação ribeirinha: saberes, vivencias e formação no campo. 2. ed. Belém: UFPA, 2013. p. 19-41.

GONÇALVES, M. A. S. Sentir, pensar, agir: corporeidade e educação. 15. ed. Campinas: Papirus, 2012.

INEP - Instituto Nacional de Estudos e Pesquisas Educacionais Anísio Teixeira. Censo escolar da educação básica 2016: notas estatísticas. Brasília-DF: Inep, 2017.

INSTITUTO AYRTON SENNA. Programa Se Liga. 2018. Available in: http://www.institutoayrtonsenna.org.br/pt-br/instituto.html. Accessed on: Jan. 10th. 2018.

MERLEAU-PONTY, M. Fenomenologia da percepção. 4. ed. São Paulo: Martins Fontes, 2011.

MINAYO, M. Pesquisa social: teoria, método e criatividade. Petrópolis: Vozes, 1994.

MORIN, E. Os sete saberes necessários à educação do futuro. São Paulo: Cortez; Brasília, DF: Unesco, 2011.

MOREIRA, W. W. Do corpo à corporeidade na educação formal: mudança paradigmática. In: FABRIN, F. C. S.; NÓBREGA, M. L. S.; TODARO, M. Á. (Org.). Corpo e educação: desafios e possibilidades. Jundiaí: Paco, 2014. p. 149-166.

MOREIRA, W. W.; SIMÕES, R.; PORTO, E. Análise de conteúdo: técnica de elaboração e análise de unidades de significado. Revista Brasileira de Ciência e Movimento, Taguatinga, v. 13, n. 4, p. 107-114, 2005.

NÓBREGA, T. P. Corporeidade e Educação Física: do corpo-objeto ao corpo-sujeito. 2. ed. Natal: UFRN, 2005.

NÓBREGA, T. P. Uma fenomenologia do corpo. São Paulo: Física, 2010.

RIBEIRO, M. Educação Rural. In: CALDART, R. S. et al. (Org.). Dicionário da Educação do Campo. Rio de Janeiro: Escola Politécnica de Saúde Joaquim Venâncio; São Paulo: Expressão Popular, 2012.

SIANI, S. R.; CORREA, D. A.; CASAS, A. L. Fenomenologia, método fenomenológico e pesquisa empírica: 0 instigante universo da construção de conhecimento esquadrinhada na experiência de vida. Revista de Administração da Unimep, Piracicaba, v. 14, n. 1, p. 116-219, 2016. 


\section{Rosenilma Branco Rodrigues (Brasil, Pará, Santarém) Universidade Federal do Oeste do Pará (Ufopa)}

Master in Education from the Federal University of Western Pará (Ufopa), graduated in Philosophy from the Pan American College (FPA) and graduated in Tourism from the Hope Institute of Higher Education (lespes), with a degree in "The School and the City: educational public policies" by Ufopa. She was Professor of Philosophy and Sociology at the State Department of Education of Pará. She is a member of the Research Group Educational Cognitions and Formative Practices in School and Non-School Spaces - Ufopa.

Lattes: http://lattes.cnpq.br/6154283230706443.

E-mail: rosebrancor@yahoo.com.br.

\section{Hergos Ritor Fróes de Couto (Brasil, Pará, Santarém) \\ Universidade Federal do Oeste do Pará (Ufopa)}

Postdoctoral degree in Sports from the Faculty of Sports of the University of Porto, Portugal, developing research on the theme that involves the reconciliation of sports training with the education of young soccer players from the basic categories of Porto Clube Football, Doctor of Education by Nove de Julho University (Uninove), Master in Physical Education from the Methodist University of Piracicaba (Unimep), graduated in Pedagogy from Uninove, bachelor and bachelor of Physical Education from Uninove and bachelor of Business Administration from Sant'Anna and São Paulo Integrated Colleges. Effective Professor at the Federal University of Western Pará (Ufopa), Assistant Professor IV. It operates mainly in the fields of Education and Corporeality and Education and Sport. Lattes: http://lattes.cnpq.br/4185846607001228.

E-mail: hergos@hotmail.com.

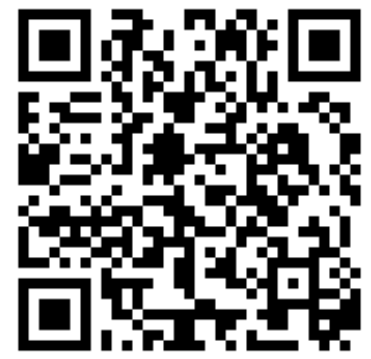

Received on July 7, 2019.

Accepted on September 23, 2019. 